\title{
Detection and Complete Genome Analysis of Circoviruses and Cycloviruses in the Small Indian Mongoose (Urva auropunctata): Identification of Novel Species
}

\author{
Kerry Gainor ${ }^{1}$, Anne A. M. J. Becker ${ }^{1}\left(\mathbb{D}\right.$, Yashpal S. Malik $^{2}\left(\mathbb{D}\right.$ and Souvik Ghosh ${ }^{1, *(D)}$ \\ 1 Department of Biomedical Sciences, Ross University School of Veterinary Medicine, \\ Basseterre P.O. Box 334, Saint Kitts and Nevis, West Indies; KerryGainor@students.rossu.edu (K.G.); \\ ABecker@rossvet.edu.kn (A.A.M.J.B.) \\ 2 College of Animal Biotechnology, Guru Angad Dev Veterinary and Animal Science University, \\ Ludhiana 141001, India; malikyps@gmail.com \\ * Correspondence: souvikrota@gmail.com or sghosh@rossu.edu; Tel.: +1-(869)-4654161 (ext. 401-1202)
}

check for updates

Citation: Gainor, K.; Becker, A.A.M.J.; Malik, Y.S.; Ghosh, S. Detection and Complete Genome Analysis of Circoviruses and Cycloviruses in the Small Indian Mongoose (Urva auropunctata): Identification of Novel Species. Viruses 2021, 13, 1700. https:/ / doi.org/10.3390/v13091700

Academic Editor: Subir Sarker

Received: 26 July 2021

Accepted: 24 August 2021

Published: 27 August 2021

Publisher's Note: MDPI stays neutral with regard to jurisdictional claims in published maps and institutional affiliations.

Copyright: (c) 2021 by the authors. Licensee MDPI, Basel, Switzerland. This article is an open access article distributed under the terms and conditions of the Creative Commons Attribution (CC BY) license (https:/ / creativecommons.org/licenses/by/ $4.0 /)$.

\begin{abstract}
Fecal samples from 76 of 83 apparently healthy small Indian mongooses (Urva auropunctata) were PCR positive with circovirus/cyclovirus pan-rep (replicase gene) primers. In this case, 30 samples yielded high quality partial rep sequences ( $400 \mathrm{bp}$ ), of which 26 sequences shared maximum homology with cycloviruses from an arthropod, bats, humans or a sheep. Three sequences exhibited maximum identities with a bat circovirus, whilst a single sequence could not be assigned to either genus. Using inverse nested PCRs, the complete genomes of mongoose associated circoviruses (Mon-1, -29 and -66) and cycloviruses (Mon-20, -24, -32, -58, -60 and -62) were determined. Mon-1, $-20,-24,-29,-32$ and -66 shared $<80 \%$ maximum genome-wide pairwise nucleotide sequence identities with circoviruses/cycloviruses from other animals/sources, and were assigned to novel circovirus, or cyclovirus species. Mon-58, -60 and -62 shared maximum pairwise identities of $79.90-80.20 \%$ with human and bat cycloviruses, which were borderline to the cut-off identity value for assigning novel cycloviral species. Despite high genetic diversity, the mongoose associated circoviruses/cycloviruses retained the various features that are conserved among members of the family Circoviridae, such as presence of the putative origin of replication (ori) in the $5^{\prime}$-intergenic region, conserved motifs in the putative replication-associated protein and an arginine rich region in the amino terminus of the putative capsid protein. Since only fecal samples were tested, and mongooses are polyphagous predators, we could not determine whether the mongoose associated circoviruses/cycloviruses were of dietary origin, or actually infected the host. To our knowledge, this is the first report on detection and complete genome analysis of circoviruses/cycloviruses in the small Indian mongoose, warranting further studies in other species of mongooses.
\end{abstract}

Keywords: circovirus; cyclovirus; small Indian mongoose; complete genome analysis; novel species

\section{Introduction}

Viruses belonging to the family Circoviridae (genera Circovirus and Cyclovirus) contain a covalently closed, circular, single-stranded DNA genome ( 1.7-2.1 kb in size) [1,2]. The circovirus and cyclovirus genomes have an ambisense organization, consisting of at least two inversely arranged open reading frames (ORFs) that encode the replication-associated protein (Rep) and the capsid protein (Cp) [1,2]. In circoviruses, the ORF coding for the Rep is organized on the virion-sense (positive-sense) strand, whilst the cycloviral Rep is encoded by the complementary (anti-sense) strand of a double-stranded DNA replicative form. The Rep is the most conserved protein in circoviruses/cycloviruses and contains sequence motifs that are characteristic of proteins participating in rolling-circle replication (RCR) $[1,2]$. On the other hand, the $\mathrm{Cp}$ has been found to be significantly more divergent and is characterized by the presence of an arginine/basic amino acid (aa) rich region in the amino terminus that might be involved in DNA binding activity [1-5]. 
Circovirus and cyclovirus genomes contain two intergenic regions (IR) that are located between the initiation codons ( $5^{\prime}$-IR) and between the stop codons ( $3^{\prime}$-IR) of the rep and $c p$ genes, although cycloviruses lacking the $3^{\prime}$-IR have also been reported [1-5]. The $5^{\prime}-$ IR contains the origin of replication (ori), characterized by a conserved nonanucleotide motif (nAnTATTAC, where ' $n$ ' represents any nucleotide (nt)) at the apex of a stem-loop structure $[1,2,6,7]$. The $3^{\prime}$-IR is shorter than $5^{\prime}-\mathrm{IR}$, and consistently smaller in cycloviruses than those observed in circoviruses [1-5].

Based on genome-wide pairwise nt sequence identities and phylogenetic analysis, the International Committee on Taxonomy of Viruses (ICTV) has recognized at least 49 and 52 species within the genera Circovirus and Cyclovirus, respectively [https://talk. ictvonline.org/ictv-reports/ictv_online_report/ssdna-viruses/w / circoviridae, accessed 10 July 2021]. Circoviruses and cycloviruses have been reported in various mammals, birds and arthropods [1-5,8-23]. Circoviruses have also been detected in fish and reptiles [2,23-28]. Despite identification in a wide variety of animals, only some circovirus species have been associated with clinical conditions [15,29-35], notable among which are porcine circovirus 2 associated diseases in pigs $[17,29]$ and beak and feather disease virus associated psittacine beak and feather disease in wild and captive psittacine birds [30]. Furthermore, circovirus infection has been related to lymphopenia and immunosuppression [1,2]. On the other hand, since the current members of the genus Cyclovirus were discovered by molecular methods, their definitive host/s and pathogenesis are largely unknown $[1,2,4]$, although cycloviruses have been detected in humans with paraplegia [36] and pneumonia [19]. The detection of many of the cycloviruses in the gut/fecal samples also indicate a possible origin from consumed food, or enteric parasites [1,2,4,21].

Mongooses are small terrestrial carnivores that belong to the family Herpestidae [37,38]. Due to their invasive and scavenging behavior, and proximity to humans and other animals, mongooses can serve as potential carriers of viral pathogens $[37,39,40]$. However, to date, limited virological studies have been conducted in mongoose populations. Mongooses are recognized as an important enzootic reservoir of the rabies virus, especially in the Caribbean region [39], and have been shown to be a reservoir animal for hepatitis E virus on Okinawa Island, Japan [40]. Other viruses reported in mongooses include Carnivore protoparvovirus 1, cowpox virus, feline panleukopenia virus, picobirnavirus and thogoto virus [41-45]. Among the eukaryotic circular Rep-encoding single-stranded DNA (CRESS DNA) viruses, four novel gemycircularviruses were detected in an Egyptian mongoose (Herpestes ichneumon) [46]. In the present study, we report for the first-time detection and complete genomic analysis of circoviruses and cycloviruses in the small Indian mongoose (Urva auropunctata).

\section{Materials and Methods}

\subsection{Ethics Statement}

This study received approval from the Institutional Animal Care and Use Committee (IACUC) of the Ross University School of Veterinary Medicine, St. Kitts and Nevis (IACUC protocol title: trapping and necropsy for mongoose microbial ecology study. Approved IACUC protocol number: 17.04.13, dated 13 April 2017).

\subsection{Sample Collection}

During April-July 2017, non-diarrheic fecal samples were obtained from the rectum and distal part of the colon of 83 small Indian mongooses that were trapped, euthanized and necropsied under sterile conditions for a gut microbiome study on the Caribbean island of St. Kitts [47]. The samples were kept at $-80^{\circ} \mathrm{C}$ until further analyses.

\subsection{Amplification of Viral DNA}

Viral DNA was extracted from the fecal samples using the QIAamp Fast DNA Stool Mini Kit (Qiagen Sciences, Germantown, MD, USA) following the instructions provided by the manufacturer. The samples were screened for the presence of circoviruses and 
cycloviruses by nested PCR assays using pan-rep primers (primers CV-F1, CV-R1, CV-F2 and CV-R2, targeting a short stretch ( 400 bp) of the Rep-encoding ORF), as described previously [3]. Additional primers were designed from the partial Rep-encoding ORF sequences and used in inverse nested PCRs to amplify the complete genomes of the mongoose associated circovirus and cyclovirus (Supplementary material S1). PCRs were performed using the Platinum ${ }^{\mathrm{TM}}$ Taq DNA Polymerase (Invitrogen ${ }^{\mathrm{TM}}$, Thermo Fisher Scientific Corporation, Waltham, MA, USA) according to the manufacturer's instructions. Sterile water was used as a negative control in all PCR reactions.

\subsection{Nucleotide Sequencing}

The PCR amplicons were purified using the Wizard ${ }^{\circledR}$ SV Gel and PCR Clean-Up kit (Promega, Madison, WI, USA) following the instructions provided by the manufacturer. Nucleotide sequences were obtained using the ABI Prism Big Dye Terminator Cycle Sequencing Ready Reaction Kit (Applied Biosystems, Foster City, CA, USA) on an ABI 3730XL Genetic Analyzer (Applied Biosystems, Foster City, CA, USA).

\subsection{Sequence Analysis}

Homology search for related nt and deduced aa sequences were performed using the standard BLASTN and BLASTP program (Basic Local Alignment Search Tool, www. ncbi.nlm.nih.gov /blast, accessed on 22 June 2021), respectively. Putative ORFs encoding the viral Rep and Cp were identified using the ORF finder (https: / /www.ncbi.nlm.nih. gov / orffinder/, accessed on 20 June 2021), whilst those with a putative intron between the Rep coding sequences (CDS) were determined by BLASTN analysis with the CDS feature. Pairwise sequence (\%) identities for the complete viral genomes, and the putative Rep and Cp were determined using the MUSCLE algorithm in the SDTv1.2 program, as described previously $[2,48]$. On the other hand, pairwise identities between the partial Rep-encoding ORF sequences were calculated using the MUSCLE alignment program (https:/ / www.ebi.ac.uk/Tools/msa/muscle/, accessed on 23 June 2021) and the 'align two or more sequences' option of BLASTN program (https://blast.ncbi.nlm.nih.gov/, accessed on 23 June 2021). The maps of the circular viral genomes were constructed with the 'Draw Custom Plasmid Map' program (https:/ / www.rf-cloning.org/savvy.php, accessed on 20 June 2021). The putative stem-loop structure was identified in the viral genome using the mFold program [49].

Multiple alignments of $n t$ and deduced aa sequences were carried out using the MUSCLE algorithm embedded in the MEGA7 software [50]. Phylogenetic analysis was performed by the maximum likelihood (ML) method using the MEGA7 software [50], with the GTR+G model of substitution and 1000 bootstrap replicates, as described previously [2] The complete genomes of the mongoose associated circoviruses and cycloviruses were investigated for recombination events using the RDP4 program with default parameters [51]. A circovirus/cyclovirus sequence was determined as a recombinant if it was supported by two, or more than two detection methods (3Seq, BOOTSCAN, CHIMERA, GENECONV, MAXCHI, RDP and SISCAN) with a highest acceptable $p$-value of $p<0.01$ with Bonferroni's correction $[17,51]$.

\subsection{GenBank Accession Numbers}

The GenBank accession numbers for the mongoose associated CRESS DNA viral sequences determined in this study are MZ382570-MZ382599.

\section{Results and Discussion}

\subsection{Detection of Circoviruses and Cycloviruses in the Small Indian Mongoose}

The small island of St. Kitts ( $\sim 69$ square miles, human population of $\sim 35,000)$ is inhabited by a large population of the small Indian mongoose $(\sim 45,000)$ that dwell in wild and urban habitats (Figure 1A,B) [44,52], [https://www.sknbs.org/about-bureau/ about-st-kitts-and-nevis/, accessed on 14 July 2021]. In the present study, single fecal 
samples from $76(91.56 \%)$ of the 83 small Indian mongooses yielded the expected $\sim 400 \mathrm{bp}$ amplicon with circovirus/cyclovirus pan-rep primers in screening PCR assays. In this case, 39 of the 76 positive samples showed strong PCR amplification and were sequenced for the partial rep gene. By BLASTN analysis, all the mongoose-associated partial CRESS DNA viral sequences shared maximum homology with published circovirus, or cyclovirus rep gene sequences, except for Mon-66, which shared maximum pairwise nt sequence identities of $63.37 \%$ with that of an unclassified CRESS DNA virus (GenBank accession number KY487932) from a wastewater sample (Table 1). However, based on analysis of the complete genome sequence, Mon-66 was assigned to the genus Circovirus (Table 2). Nine of the partial rep sequences lacked high quality and were excluded from further analysis.

(A)

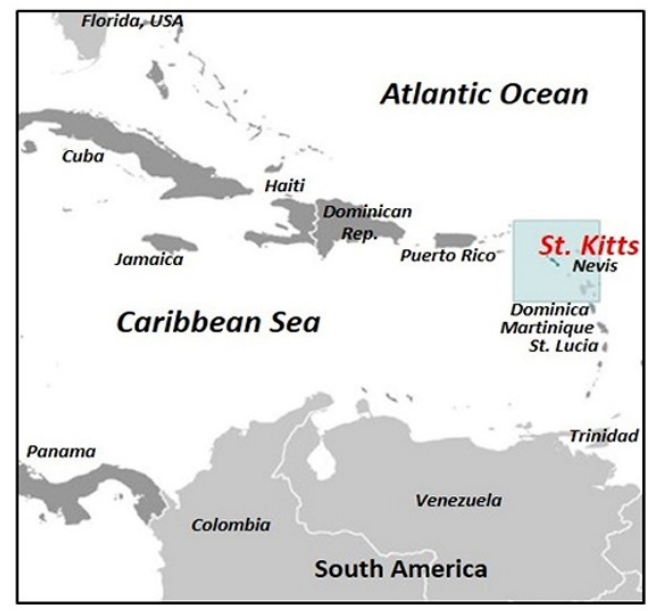

(B)

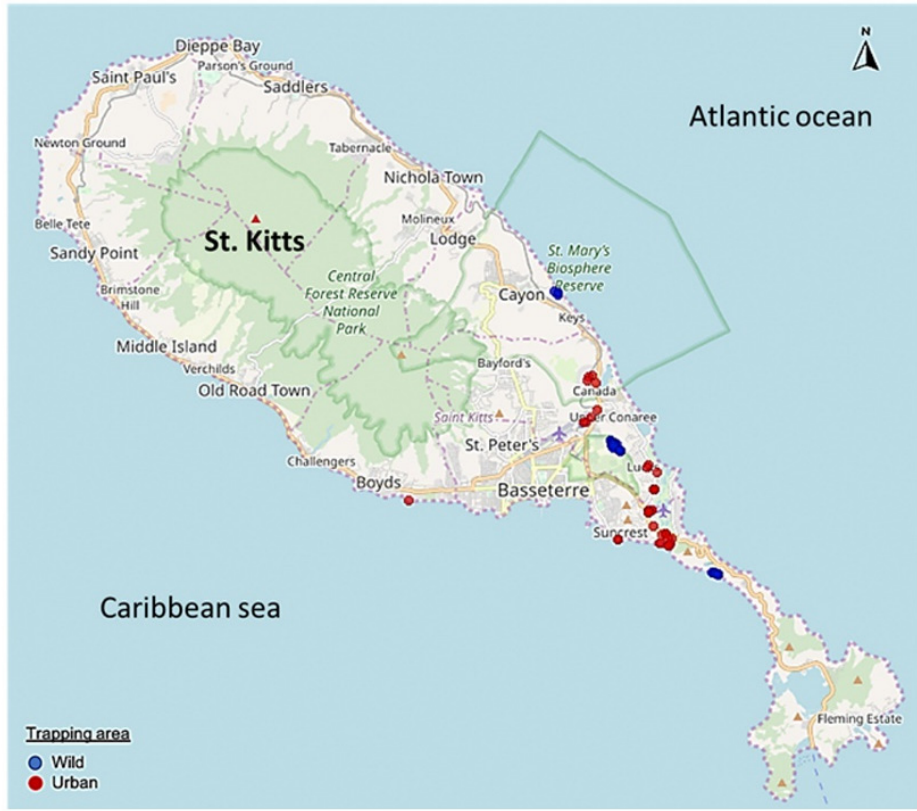

Figure 1. (A) Geographical location of the Caribbean island of St. Kitts. The map in Figure 1A was obtained from https:/ / www.cia.gov/library/publications/the-world-factbook (accessed on 1 April 2021). (B) Map of St. Kitts showing the mongoose trapping sites. The trapping sites in the wild and urban habitats are shown with blue and red, respectively. The figure originally appeared in Kleymann et al., 2020 [44], and was used here with permission from the corresponding author of the publication [44]. 


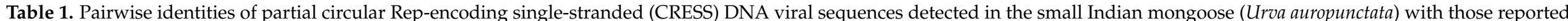

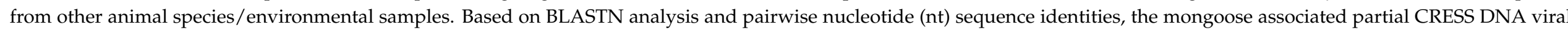

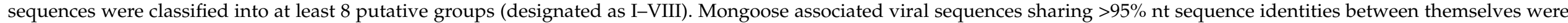
assigned to the same group and are highlighted with the same color.

\begin{tabular}{|c|c|c|c|c|}
\hline $\begin{array}{l}\text { CRESS DNA Viral Sequence from } \\
\text { the Small Indian Mongoose }\end{array}$ & $\begin{array}{l}\text { Putative } \\
\text { Group }\end{array}$ & $\begin{array}{l}\text { Length of High Quality nt } \\
\text { Sequence Analyzed }{ }^{1}\end{array}$ & GenBank Accession Number & $\begin{array}{c}\text { Maximum Pairwise nt Sequence (\%) Identity with Cognate } \\
\text { CRESS Viral DNA Sequence (Virus Name/Detected in } \\
\text { Animal, or Environment/Country/Year of } \\
\text { Detection/GenBank Accession Number) from Other } \\
\text { Animal Species, or Environment }{ }^{2}\end{array}$ \\
\hline Mon- $1^{3}$ & I & $358 \mathrm{nt}$ & MZ382570 & $\begin{array}{c}77.65 \% \text { with Bat circovirus isolate } \\
\text { C072/Bat/China/2015/KX834490 }\end{array}$ \\
\hline Mon-2 & II & $463 \mathrm{nt}$ & MZ382579 & $\begin{array}{l}97.62 \% \text { with Pacific flying fox associated } \\
\text { cyclovirus-3/Bat/Tonga/2015/KT732789 }\end{array}$ \\
\hline Mon-3 & III & $364 \mathrm{nt}$ & MZ382580 & $\begin{array}{c}\text { 94.25\% with Cockroach-associated cyclovirus/Palmetto } \\
\text { bug/USA/2011/JX569794 }\end{array}$ \\
\hline Mon-10 & IV & $390 \mathrm{nt}$ & MZ382582 & $\begin{array}{c}\text { 97.18\% with Cyclovirus } \\
\text { TN2/Human/Tunisia/2005/GQ404904 }\end{array}$ \\
\hline Mon-14 & IV & $381 \mathrm{nt}$ & MZ382583 & $\begin{array}{c}\text { 97.38\% with Cyclovirus } \\
\text { TN2/Human/Tunisia/2005/GQ404904 }\end{array}$ \\
\hline Mon-16 & V & $363 \mathrm{nt}$ & MZ382584 & $\begin{array}{c}\text { 93.11\% with Cyclovirus } \\
\text { NG_sheep50/Sheep/Nigeria/2009/GQ404982 }\end{array}$ \\
\hline Mon-18 & IV & $324 \mathrm{nt}$ & MZ382585 & $\begin{array}{l}\text { 95.37\% with Cyclovirus } \\
\text { TN2/Human/Tunisia/2005/GQ404904 }\end{array}$ \\
\hline Mon- $20^{3}$ & VI & $364 \mathrm{nt}$ & MZ382573 & $\begin{array}{c}\text { 77.47\% with Bat cyclovirus isolate } \\
\text { CyV-LimbeP14/Bat/Cameroon/2013/MG693173 } 3 \\
\end{array}$ \\
\hline Mon-22 & IV & $343 \mathrm{nt}$ & MZ382586 & $\begin{array}{c}\text { 96.79\% with Cyclovirus } \\
\text { TN2/Human/Tunisia/2005/GQ404904 }\end{array}$ \\
\hline Mon- $24^{3}$ & VI & $364 \mathrm{nt}$ & MZ382574 & $\begin{array}{c}\text { 77.47\% with Bat cyclovirus isolate } \\
\text { CyV-LimbeP14/Bat/Cameroon/2013/MG693173 } 3\end{array}$ \\
\hline Mon-25 & IV & $372 \mathrm{nt}$ & MZ382587 & $\begin{array}{c}\text { 97.04\% with Cyclovirus } \\
\text { TN2/Human/Tunisia/2005/GQ404904 }\end{array}$ \\
\hline Mon-29 3 & I & $358 \mathrm{nt}$ & MZ382571 & $\begin{array}{l}77.65 \% \text { with Bat circovirus isolate } \\
\text { C072/Bat/China/2015/KX834490 }\end{array}$ \\
\hline Mon-32 3 & IV & $363 \mathrm{nt}$ & MZ382572 & $\begin{array}{c}\text { 97.25\% with Cyclovirus } \\
\text { TN2/Human/Tunisia/2005/GQ404904 } \\
3\end{array}$ \\
\hline
\end{tabular}


Table 1. Cont.

\section{CRESS DNA Viral Sequence from \\ the Small Indian Mongoose}

\section{Putative \\ Group}

\section{Length of High Quality nt \\ Sequence Analyzed ${ }^{1}$}

\section{GenBank Accession Number}

Maximum Pairwise nt Sequence (\%) Identity with Cognate

CRESS Viral DNA Sequence (Virus Name/Detected in

Animal, or Environment/Country/Year of

Detection/GenBank Accession Number) from Other

Animal Species, or Environment ${ }^{2}$

\begin{tabular}{|c|c|c|c|c|}
\hline Mon-33 & I & $327 \mathrm{nt}$ & MZ382588 & $\begin{array}{l}\text { 79.20\% with Bat circovirus isolate } \\
\text { C072/Bat/China/2015/KX834490 }\end{array}$ \\
\hline Mon-36 & VI & $281 \mathrm{nt}$ & MZ382589 & $\begin{array}{c}\text { 82.21\% with Bat cyclovirus isolate } \\
\text { CyV-LimbeP14/Bat/Cameroon/2013/MG693173 }\end{array}$ \\
\hline Mon-37 & IV & $374 \mathrm{nt}$ & MZ382590 & $\begin{array}{c}\text { 96.79\% with Cyclovirus } \\
\text { TN2/Human/Tunisia/2005/GQ404904 }\end{array}$ \\
\hline Mon-39 & IV & $350 \mathrm{nt}$ & MZ382591 & $\begin{array}{c}\text { 96.86\% with Cyclovirus } \\
\text { TN2/Human/Tunisia/2005/GQ404904 }\end{array}$ \\
\hline Mon-41 & IV & $354 \mathrm{nt}$ & MZ382592 & $\begin{array}{c}\text { 97.18\% with Cyclovirus } \\
\text { TN2/Human/Tunisia/2005/GQ404904 }\end{array}$ \\
\hline Mon-45 & VI & $275 \mathrm{nt}$ & MZ382594 & $\begin{array}{c}\text { 81.45\% with Bat cyclovirus isolate } \\
\text { CyV-LimbeP14/Bat/Cameroon/2013/MG693173 }\end{array}$ \\
\hline Mon-56 & IV & $366 \mathrm{nt}$ & MZ382595 & $\begin{array}{c}\text { 97.27\% with Cyclovirus } \\
\text { TN2/Human/Tunisia/2005/GQ404904 }\end{array}$ \\
\hline Mon- $58^{3}$ & VII & $428 \mathrm{nt}$ & MZ382575 & $\begin{array}{c}\text { 91.84\% with Human cyclovirus } \\
\text { VS5700009/Human/Malawi/2010-2011/KC771281 }{ }^{3}\end{array}$ \\
\hline Mon-59 & II & $472 \mathrm{nt}$ & MZ382596 & $\begin{array}{c}98.31 \% \text { with Pacific flying fox associated } \\
\text { cyclovirus-3/Bat/Tonga/2015/KT732789 }\end{array}$ \\
\hline Mon- $60^{3}$ & VII & $428 \mathrm{nt}$ & MZ382576 & $\begin{array}{c}\text { 91.84\% with Human cyclovirus } \\
\text { VS5700009/Human/Malawi/2010-2011/KC771281 }{ }^{3}\end{array}$ \\
\hline Mon-61 & IV & $354 \mathrm{nt}$ & MZ382597 & $\begin{array}{c}\text { 96.61\% with Cyclovirus } \\
\text { TN2/Human/Tunisia/2005/GQ404904 }\end{array}$ \\
\hline Mon- $62^{3}$ & VII & $428 \mathrm{nt}$ & MZ382577 & $\begin{array}{c}\text { 92.07\% with Human cyclovirus } \\
\text { VS5700009/Human/Malawi/2010-2011/KC771281 }{ }^{3}\end{array}$ \\
\hline Mon- $66^{3}$ & VIII & $370 \mathrm{nt}$ & MZ382578 & $\begin{array}{l}\text { 63.37\% with Uncultured virus clone CG263/Environmental } \\
\text { sample/USA/2015/KY487932 }{ }^{3}\end{array}$ \\
\hline Mon-71 & IV & $284 \mathrm{nt}$ & MZ382598 & $\begin{array}{c}\text { 97.18\% with Cyclovirus } \\
\text { TN2/Human/Tunisia/2005/GQ404904 }\end{array}$ \\
\hline Mon-76 & IV & $374 \mathrm{nt}$ & MZ382599 & $\begin{array}{c}\text { 97.33\% with Cyclovirus } \\
\text { TN2/Human/Tunisia/2005/GQ404904 }\end{array}$ \\
\hline
\end{tabular}

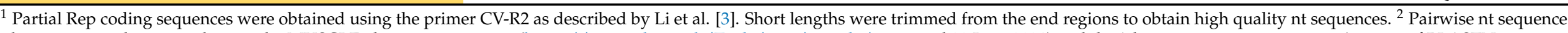

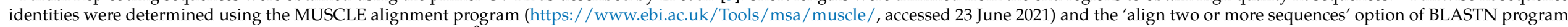

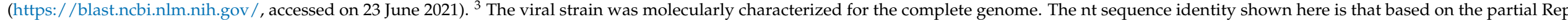
coding sequence. 


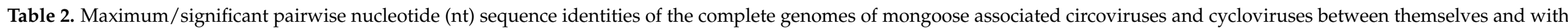
those from other animal species.

\begin{tabular}{|c|c|c|c|}
\hline \multirow[b]{2}{*}{$\begin{array}{l}\text { Mongoose associated } \\
\text { circovirus }\end{array}$} & \multirow[b]{2}{*}{$\begin{array}{l}\text { GenBank accession } \\
\text { number }\end{array}$} & \multicolumn{2}{|c|}{ Maximum/Significant Pairwise nt Sequence (\%) Identities ${ }^{1}$} \\
\hline & & Between mongoose associated circoviruses & $\begin{array}{l}\text { With circovirus (Strain Name/Detected in Animal } \\
\text { Species/Country/Year/GenBank Accession Number) from other animal species }\end{array}$ \\
\hline Mon-1 & MZ382570 & $99.60 \%$ with Mon-29 & $\begin{array}{c}\text { 67.40\% with Bat circovirus isolate BtPspp.-CV/GD2012/Bat/China/2012/KJ641716 } \\
\text { 66.90\% with Bat associated circovirus 10, isolate } \\
\text { HK02976/Bat/Japan/2013/LC456717 }\end{array}$ \\
\hline Mon-29 & MZ382571 & $99.60 \%$ with Mon-1 & $\begin{array}{c}\text { 67.20\% with Bat circovirus isolate BtPspp.-CV/GD2012/Bat/China/2012/KJ641716 } \\
\text { 66.60\% with Bat associated circovirus 10, isolate } \\
\text { HK02976/Bat/Japan/2013/LC456717 }\end{array}$ \\
\hline $\begin{array}{l}\text { Mongoose associated } \\
\text { cyclovirus }\end{array}$ & & $\begin{array}{l}\text { Between mongoose associated } \\
\text { cycloviruses }\end{array}$ & $\begin{array}{c}\text { With cyclovirus (Strain name/Detected in animal } \\
\text { species/Country/Year/GenBank accession number) from other animal species }\end{array}$ \\
\hline Mon-20 & $\begin{array}{l}\text { MZ382573 } \\
\text { MZ382574 }\end{array}$ & $100 \%$ between Mon- 20 and Mon- 24 & $\begin{array}{c}\text { 72.10\% with Bat cyclovirus isolate CyV-LysokaP4/Bat/Cameroon/2013/MG693174 } \\
\text { 71.50\% with Bat cyclovirus isolate } \\
\text { CyV-LimbeP14/Bat/Cameroon/2013/MG693173 }\end{array}$ \\
\hline Mon-32 & MZ382572 & $65.70 \%$ with Mon-20 and Mon-24 & $\begin{array}{l}\text { 77.30\% with Cyclovirus isolate PKgoat11/Goat/Pakistan/2009/HQ738636 } \\
\text { 75.30\% with Cyclovirus isolate PK5006/Human/Pakistan/2007/GQ404844 }\end{array}$ \\
\hline Mon-58 & MZ382575 & $99.30 \%$ with Mon-60 and Mon-62 & $\begin{array}{c}\text { 80.20\% with Human cyclovirus isolate } \\
\text { VS570000/Human/Malawi/2010-2011/KC771281 } \\
\text { 80.20\% with Pacific flying fox associated cyclovirus-3 isolate } \\
\text { Tbat_H_103923/Bat/Tonga/2015/KT732788 }\end{array}$ \\
\hline Mon-60 & MZ382576 & $\begin{array}{l}99.50 \% \text { with Mon-62 } \\
99.30 \% \text { with Mon-58 }\end{array}$ & $\begin{array}{c}\text { 79.90\% with Human cyclovirus isolate } \\
\text { VS570000/Human/Malawi/2010-2011/KC771281 } \\
\text { 79.90\% with Pacific flying fox associated cyclovirus-3 isolate } \\
\text { Tbat_H_103923/Bat/Tonga/2015/KT732788 }\end{array}$ \\
\hline Mon-62 & MZ382577 & $\begin{array}{l}99.50 \% \text { with Mon-60 } \\
99.30 \% \text { with Mon-58 }\end{array}$ & $\begin{array}{c}\text { 80.00\% with Pacific flying fox associated cyclovirus-3 isolate } \\
\text { Tbat_H_103923/Bat/Tonga/2015/KT732788 } \\
\text { 79.90\% with Human cyclovirus isolate } \\
\text { VS570000/Human/Malawi/2010-2011/KC771281 }\end{array}$ \\
\hline
\end{tabular}

${ }^{1}$ The pairwise nt sequence (\%) identities were determined using the Sequence Demarcation Tool Version 1.2 (SDTv1.2) with the MUSCLE alignment algorithm, as described previously [2]. 
Based on BLASTN analysis and pairwise nt sequence identities of partial rep, the mongoose associated partial CRESS DNA viral sequences were classified into at least 8 putative groups (designated as I-VIII) (Table 1). Mongoose associated partial rep sequences sharing $>95 \%$ pairwise identities between themselves were assigned to the same group (Table 1). Group-I sequences shared maximum pairwise identities of $77.65-79.20 \%$ with circovirus isolate $\mathrm{C} 072$ that was detected in the intestinal sample from a vesper bat (Myotis fimbriatus) in China (Table 1). Group II-VII exhibited maximum homology with cyclovirus rep sequences (Table 1). Group-II and -VI sequences shared maximum homology (pairwise identities of $97.62-98.31 \%$ and $77.47-82.21 \%$, respectively) with cycloviruses from bats (Table 1). Group-III and -V consisted of a single rep sequence each, and shared maximum pairwise identities of $94.25 \%$ and $93.11 \%$ with a cockroach associated cyclovirus and a sheep associated cyclovirus, respectively (Table 1). Group-IV was the largest, consisting of 15 partial rep sequences that shared maximum pairwise identities of $95.37-97.48 \%$ with human cyclovirus TN2 (detected in fecal sample of a healthy child who came in contact with a non-polio-infected acute flaccid paralysis patient [3]). Group-VII sequences shared maximum homology (pairwise identities of 91.84-92.07\%) with human cyclovirus VS5700009 that was detected in the serum of a patient with unexplained paraplegia [36].

Even though we reported high rates of detection of CRESS DNA viral sequences that exhibited maximum homology with circoviruses, or cycloviruses, all the fecal samples were obtained from apparently healthy mongooses, indicating a lack of association between these viruses and clinical conditions. Circoviruses appear to primarily infect vertebrates, whilst those detected in hematophagous arthropod vectors might actually be viruses of mammals, or birds that these insects feed upon $[2,5,21,23]$. On the other hand, cycloviruses have been reported in a wide array of both invertebrates and mammals $[2,5,21,23]$. Based on these observations, it has been proposed that cycloviruses are more diverse and widespread than circoviruses $[2,5,21,23]$. In the present study, $90 \%(35 / 39)$ of the partial rep sequences shared maximum pairwise identities with cycloviruses, which constituted 6 of the $8 \mathrm{pu}-$ tative groups of diverse CRESS DNA viral sequences (Table 1). Since only fecal samples were analyzed, and the small Indian mongoose has been known to feed on small mammals, reptiles, birds, bird and reptile eggs, crustaceans, insects and human waste [53], we could not determine whether the mongoose associated CRESS DNA viruses replicated in the host or were of dietary origin.

Based on the detection of closely related circoviruses/cycloviruses in different animal species, especially in tissues, some studies have proposed interspecies transmission events within the family Circoviridae [2,3,5,54]. In this study, 15 (group-IV) and 2 (group-II) of the mongoose associated partial rep sequences were closely related $(>95 \%$ pairwise $n t$ identities) to cycloviruses from humans and bats, respectively (Table 1). St. Kitts island has a sizeable bat population [55], and the small Indian mongoose has often been seen in close proximity to humans [44], offering an ideal environment for interspecies transmission events. However, we could not obtain the full-length genome sequences for group-II viruses, whilst that of complete genome of human cyclovirus TN2 (closely related to groupIV sequences) was not available in the GenBank database. Furthermore, caution should be exercised whilst commenting on cross-species transmission of circoviruses/cycloviruses from fecal samples, as they may have a dietary origin [2,3,5,54], especially in mongooses that have a wide-range of feeding habits [53]. Interestingly, one of the mongoose associated partial rep sequences (group-III) shared maximum homology with a cockroach associated cyclovirus, corroborating previous observations that cyclovirus sequences detected in vertebrate samples might be actually those from viruses of arthropods [21,23] (Table 1).

\subsection{Analysis of the Complete Genomes of Mongoose Associated Circoviruses and Cycloviruses}

Since the ICTV classification scheme for the family Circoviridae is based on genomewide pairwise identities [1,2], attempts were made to determine the complete genome sequences of mongoose associated CRESS DNA viruses representing the putative groups I-VIII (Table 1). Using an inverse nested PCR assay, we obtained the full-length genome 
sequences of 2 group-I (Mon-1 and -29), a single group-IV (Mon-32), 2 group-VI (Mon-20 and -24), 3 group-VII (Mon-58, -60 and -62) and a single group-VIII (Mon-66) viruses (Tables 1 and 2), whilst the complete genomes of group-II, -III and -V viruses could not be amplified. The genomic organization of the mongoose associated circoviruses and cycloviruses are shown in Figure 2. The complete genome sequences of the mongoose associated circoviruses and cycloviruses (collectively referred to as the 'Mon sequences') retained the various features that are conserved in members of the genera Circovirus and Cyclovirus, respectively, within the family Circoviridae (Figures 2-4; Supplementary material S2) [1,2].
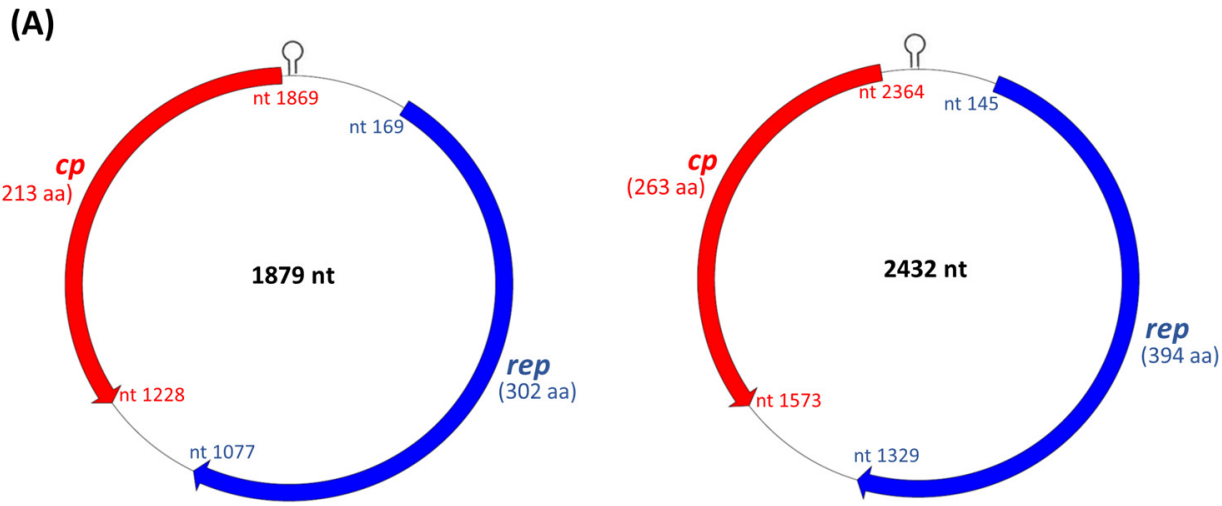

Mongoose associated circovirus strains Mon-1 and Mon-29 Mongoose associated circovirus strain Mon-66
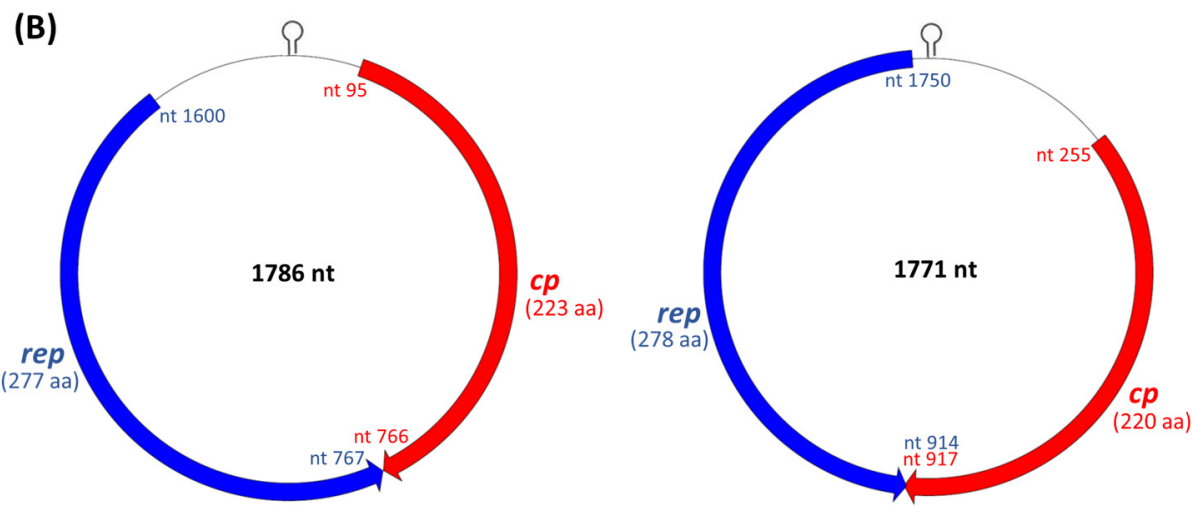

Mongoose associated cyclovirus strains Mon-20 and Mon-24

Mongoose associated cyclovirus strain Mon-32

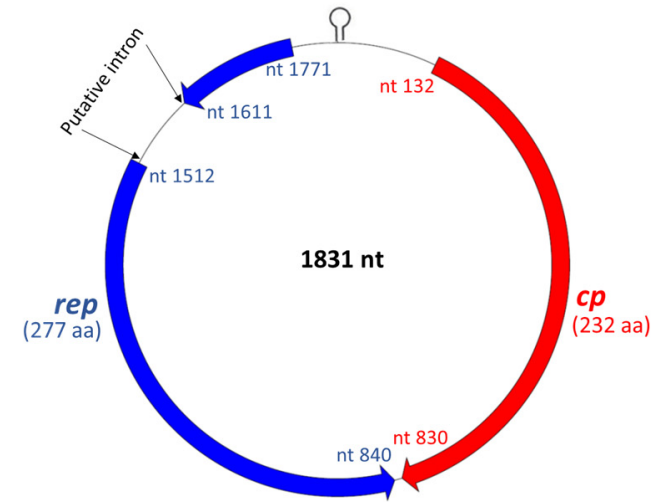

Mongoose associated cyclovirus strains Mon-58, Mon-60 and Mon-62

Figure 2. Genome organization of the mongoose associated circoviruses (A) and cycloviruses (B). The inversely arranged major open reading frames encoding the putative replication associated (Rep) and capsid (Cp) proteins are shown with blue and red arrows, respectively. The putative origin of replication (ori) characterized by a nonanucleotide motif at the apex of a stem-loop structure is marked in the $5^{\prime}$-intergenic region. The size of the Rep and $\mathrm{Cp}$ are shown in parenthesis. nt: nucleotide; aa: amino acid. 


\begin{tabular}{|c|c|}
\hline $\begin{array}{l}\text { Mongoose associated } \\
\text { circovirus }\end{array}$ & Features of the putative stem-loop structure in the 5 '-intergenic region of circovirus/cyclovirus genomes \\
\hline Mon-1 & $\begin{array}{l}5^{\prime} \\
<c p--- \text { CTTGACATTCTGGCTCCACAGTATTACCTGGAAGTTTGGAGCCAGGAGCCATTACT---rep } \rightarrow\end{array}$ \\
\hline Mon-29 & 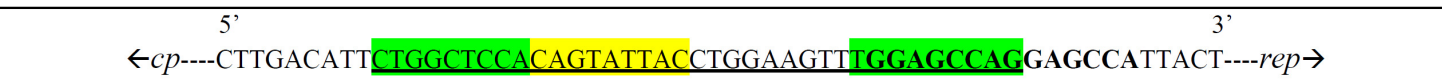 \\
\hline Mon-66 & $\begin{array}{l}5^{\prime} \\
\leftarrow c p--- \text { TAACTGAGCCCGGGTCTGGGACTAGTATTACCCCAGACCTGGGCTCAAAGCTCTATGACCCTAAGCGG----rep } \rightarrow\end{array}$ \\
\hline \multicolumn{2}{|l|}{$\begin{array}{l}\text { Mongoose associated } \\
\text { cyclovirus }\end{array}$} \\
\hline Mon-20 & 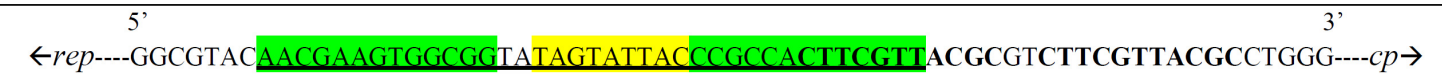 \\
\hline Mon-24 & $\begin{array}{cc}5^{\prime} & 3{ }^{\prime} \\
\leftarrow r e p--- \text { GGCGTACAACGAAGTGGCGGTATAGTATTACCCGCCACTTCGTTACGCGTCTTCGTTACGCCTGGG---cp } \rightarrow\end{array}$ \\
\hline Mon-32 & $\begin{array}{ll}5^{\prime} & 3 \\
\leftarrow r e p--- \text { CTGCAACGAAGTGACGGGTATAGTATTACCCCGTCACTTCGTAACCGTGACTTCGTAACCAATT---cp } \rightarrow\end{array}$ \\
\hline Mon-58 & 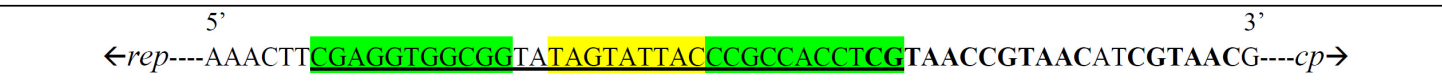 \\
\hline Mon-60 & 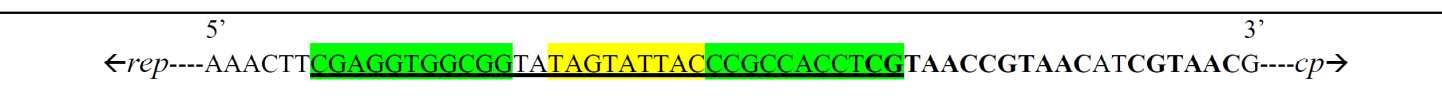 \\
\hline Mon-62 & 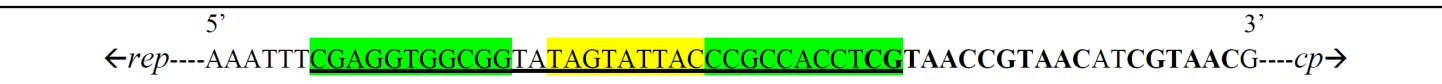 \\
\hline
\end{tabular}

Figure 3. Potential stem-loop structures found in the $5^{\prime}$-intergenic region of mongoose associated circovirus and cyclovirus genomes. The putative stem-loop sequence is underlined. The nonanucleotide motif is shown with yellow. The complementary regions of the nucleotide sequence constituting the 'putative stem' are highlighted with green. The tandem repeat motifs are shown with bold font. rep: replicase gene; $c$ : capsid gene.

\begin{tabular}{|c|c|c|c|c|c|c|}
\hline $\begin{array}{l}\text { Mongoose associated } \\
\text { circovirus }\end{array}$ & Motif I & Motif II & Motif III & Walker A & Walker B & Motif C \\
\hline Mon-1 & $\begin{array}{l}\text { CFTVNN } \\
20\end{array}$ & $\begin{array}{l}\text { PHLQG } \\
57\end{array}$ & $\begin{array}{l}\text { YCQK } \\
98\end{array}$ & $\begin{array}{l}\text { GPPGVGKT } \\
176\end{array}$ & $\begin{array}{l}\text { VFDDF } \\
214\end{array}$ & \begin{tabular}{|l} 
ITSN \\
254
\end{tabular} \\
\hline Mon-29 & $\begin{array}{l}\text { CFTVNN } \\
20\end{array}$ & $\begin{array}{l}\text { PHLQG } \\
57\end{array}$ & $\begin{array}{l}\text { YCQK } \\
98\end{array}$ & $\begin{array}{l}\text { GPPGVGKT } \\
176\end{array}$ & $\begin{array}{l}\text { VFDDF } \\
214\end{array}$ & $\begin{array}{l}\operatorname{liTSN}_{254}^{\text {ITSN }} \\
\end{array}$ \\
\hline Mon-66 & $\begin{array}{l}\text { MFTINN } \\
10\end{array}$ & $\begin{array}{l}\text { PHLQG } \\
44\end{array}$ & $\begin{array}{l}\text { YCSK } \\
83\end{array}$ & $\underset{166}{\text { GPPGTGKS }}$ & $\begin{array}{l}\text { VIDEF } \\
208\end{array}$ & ${ }_{251}^{\text {ITSN }}$ \\
\hline \multicolumn{7}{|l|}{$\begin{array}{l}\text { Mongoose associated } \\
\text { cyclovirus }\end{array}$} \\
\hline Mon-20 & $\begin{array}{l}\text { CFTWNN } \\
9\end{array}$ & $\begin{array}{l}\text { PHIQG } \\
47\end{array}$ & $\begin{array}{l}\text { YCRK } \\
87\end{array}$ & $\begin{array}{c}\text { GPPGTGKS } \\
165\end{array}$ & $\begin{array}{l}\operatorname{lIVDDF}_{206} \\
\end{array}$ & $2_{246}^{\text {ITSN }}$ \\
\hline Mon-24 & $\begin{array}{l}\text { CFTWNN } \\
9\end{array}$ & $\begin{array}{l}\text { PHIQG } \\
47\end{array}$ & $\begin{array}{l}\text { YCRK } \\
87\end{array}$ & $\begin{array}{l}\text { GPPGTGKS } \\
165\end{array}$ & $\begin{array}{l}{ }_{206}^{\text {IVDDF }} \\
\text {. }\end{array}$ & $2_{246}^{\text {ITSN }}$ \\
\hline Mon-32 & $\begin{array}{l}\text { CFTWNN } \\
10\end{array}$ & $\begin{array}{l}\text { LHLQG } \\
48\end{array}$ & $\begin{array}{l}\text { YCSK } \\
88\end{array}$ & $\begin{array}{l}\text { GPPGSGKS } \\
166\end{array}$ & $\begin{array}{l}\text { IIDDF } \\
207\end{array}$ & $\begin{array}{c}\text { ITSN } \\
247\end{array}$ \\
\hline Mon-58 & $\begin{array}{l}\text { CWTLNN } \\
10\end{array}$ & $\begin{array}{l}\text { KHLQG } \\
48\end{array}$ & $\begin{array}{l}\text { YCSK } \\
88\end{array}$ & $\begin{array}{l}\text { GKTGLGKS } \\
166\end{array}$ & $\begin{array}{l}\text { VIDDF } \\
206\end{array}$ & \begin{tabular}{|l} 
ITSN \\
246
\end{tabular} \\
\hline Mon-60 & $\begin{array}{l}\text { CWTLNN } \\
10\end{array}$ & $\begin{array}{l}\text { KHLQG } \\
48\end{array}$ & $\begin{array}{l}\text { YCSK } \\
88 \\
\end{array}$ & $\begin{array}{l}\text { GKTGLGKS } \\
166\end{array}$ & $\begin{array}{l}\text { VIDDF } \\
206\end{array}$ & \begin{tabular}{|l} 
ITSN \\
246 \\
\end{tabular} \\
\hline Mon-62 & $\begin{array}{l}\text { CWTLNN } \\
10\end{array}$ & $\begin{array}{l}\text { KHLQG } \\
48\end{array}$ & $\begin{array}{l}\text { YCSK } \\
88 \\
\end{array}$ & $\begin{array}{l}\text { GKTGLGKS } \\
166\end{array}$ & $\begin{array}{l}\text { VIDDF } \\
206\end{array}$ & $\begin{array}{l}\text { ITSN } \\
246\end{array}$ \\
\hline
\end{tabular}

Figure 4. Presence of the conserved rolling circle replication (motifs I through III) and superfamily 3 helicase (Walker A and $B$, and motif C) motifs in the putative replication-associated proteins (Rep) of mongoose associated circovirus and cyclovirus. The number below the motif sequence indicates the position of the amino acid residue in the respective putative Rep protein.

All the Mon sequences contained the putative ori in the $5^{\prime}$-IR, marked by the presence of the conserved nonanucleotide motif $((\mathrm{C} / \mathrm{T})$ AGTATTAC) at the apex of a potential stem-loop structure (Figures 2 and 3). Following ICTV guidelines [1,2], the first nt of the 
nonanucleotide motif was considered as 'position one' of the Mon sequences. Mon-1, -29 and -66 contained the putative ori in the Rep-encoding strand, whilst the putative ori was located in the Cp coding strand of Mon-20, -24, -32, -58, -60 and -62 (Figure 2). The 3'-IR was absent, or smaller in Mon-20, $-24,-32,-58,-60$ and -62 than those observed in Mon-1, -29 and -66 (Figure 2). Based on these observations, genome-wide pairwise identities, and phylogenetic analysis, Mon-1, -29 and - 66 were classified as circoviruses, whilst Mon-20, $-24,-32,-58,-60$ and -62 were assigned to the genus Cyclovirus (Figure 2, Figure 3, Figure 4, Figure 5, Figure 6; Table 2, Table 3, Table 4; Supplementary Materials S2-S5).

Corroborating previous observations [1,2], the putative Rep of the mongoose associated circoviruses and cycloviruses retained the conserved RCR (motifs I through III) and superfamily 3 helicase (Walker A and B, and motif C) motifs (Figure 4). On the other hand, the putative $\mathrm{Cp}$, although much more divergent than the Rep (Tables 3 and 4), contained the conserved arginine rich region at the amino terminus, with the exception of Mon-66 (Supplementary material S2). Since recombinants have been reported in both circoviruses and cycloviruses $[4,17,29,56-58]$, the Mon sequences were evaluated for potential recombination using the RDP4 program. However, we did not obtain reliable evidence for recombination events in the Mon sequences, except for Mon-32, which was identified by several models in the RDP4 program as minor parent to goat associated cyclovirus 1 (isolate PKgoat11, GenBank accession number HQ738636), whilst the major parent was unknown (Supplementary material S6).

The complete genomes of mongoose associated circoviruses Mon-1 and -29 were 1879 bp in size (Figure 2), which was comparable to those observed in most circoviruses [2]. Mon-1 and -29 were closely related to each other (Figure 5; Table 2, Table 3, Table 4; Supplementary Materials S3), and shared maximum pairwise identities of $67.40 \%$ and $67.20 \%$, respectively, with that of bat circovirus isolate BtPspp.-CV (GenBank accession number KJ641716) from China [59], followed by identities of $66.90 \%$ and $66.60 \%$, respectively, with bat associated circovirus 10 (isolate HK02976, GenBank accession number LC456717) from Japan (Table 2) [60]. Phylogenetically, the complete genome sequences of Mon-1 and -29 formed a distinct cluster within a clade that mostly consisted of circoviruses from bats, including isolates BtPspp.-CV and HK02976 (Figure 5). These observations were corroborated by analysis of the putative proteins (pairwise identities of Rep and $\mathrm{Cp}$, and phylogenetic analysis of Rep) of Mon-1 and -29 (Tables 3 and 4; Supplementary material S5). 


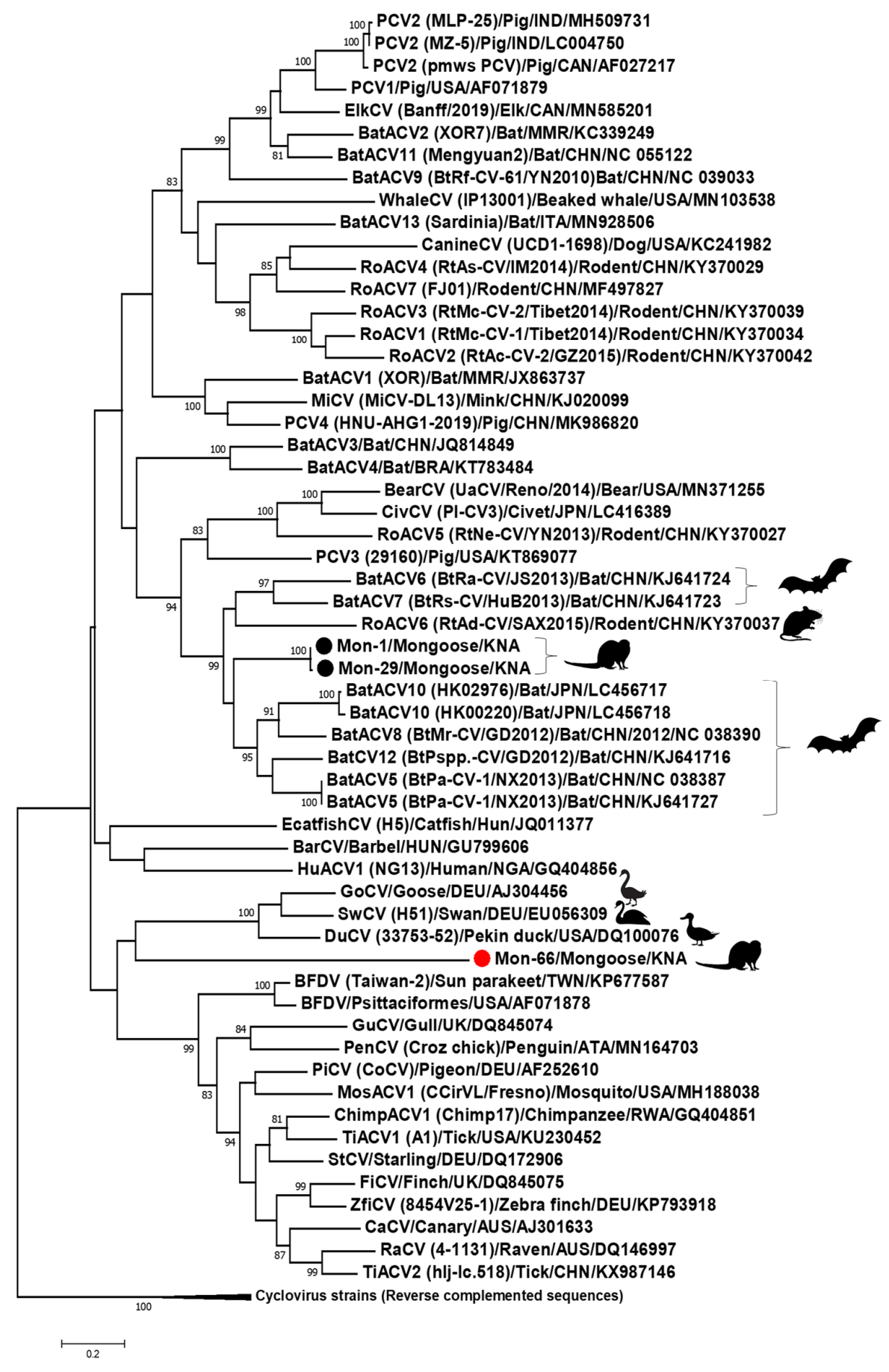

Figure 5. Phylogenetic analysis of the complete genomes of mongoose associated circoviruses (Mon-1, -29 and -66) with those of other circoviruses. The virus name/source (detected in animal species)/country are shown for the Mon sequences, while the species, or virus name (isolate)/source (detected in animal species)/country/GenBank accession number have been mentioned for the other circovirus sequences. The tree was constructed by the maximum likelihood (ML) method, with the GTR+G model of substitution and 1000 bootstrap replicates and rooted after using cyclovirus reverse complemented sequences as the outgroup. Scale bar, 0.2 substitutions per nucleotide. Bootstrap values of $<80$ is not shown. Mon- 1 and -29 are shown with black circles, whilst Mon-66 is highlighted with a red circle. BarCV: barbel circovirus; BatACV: bat associated circovirus; BFDV: beak and feather disease virus; $\mathrm{CaCV}$ : canary circovirus; ChimpACV: chimpanzee associated circovirus; CivCV: civet circovirus; CV: circovirus; DuCV: duck circovirus; EcatfishCV: European catfish circovirus; ElkCV: elk circovirus; FiCV: finch circovirus; GoCV: goose circovirus; GuCV: gull circovirus; HuACV: human associated circovirus; MiCV: mink circovirus; MosACV: mosquito associated circovirus; PenCV: penguin circovirus; PCV: porcine circovirus; PiCV: pigeon circovirus; RaCV: raven circovirus; RoACV: rodent associated circovirus; StCV: starling circovirus; SwCV: swan circovirus; TiACV: tick associated circovirus; ZfiCV: zebra fish circovirus. 


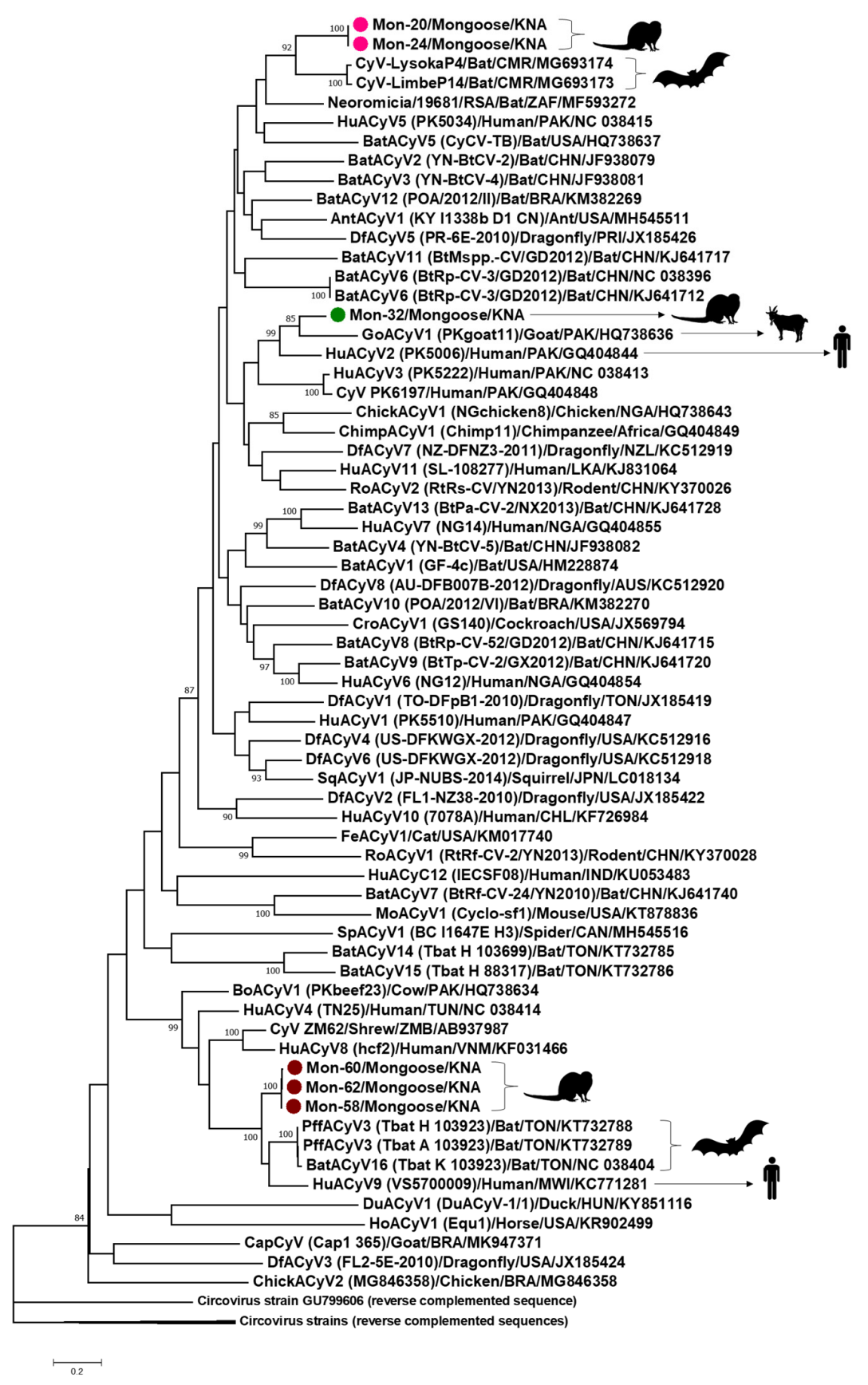

Figure 6. Phylogenetic analysis of the complete genomes of mongoose associated cycloviruses (Mon-20, -24, -32, $-58,-60$ and -62) with those of other cycloviruses. The virus name/source (detected in animal species)/country are shown for the Mon sequences, while the species, or virus name (isolate)/source (detected in animal species)/country/GenBank accession number have been mentioned for the other cyclovirus sequences. The tree was constructed by the maximum likelihood (ML) method, with the GTR + G model of substitution and 1000 bootstrap replicates and rooted after using circovirus reverse complemented sequences as the outgroup. Scale bar, 0.2 substitutions per nucleotide. Bootstrap values of $<80$ are not shown. Mon-20 and -24 are shown with pink circles, Mon-32 is highlighted with a green circle, whilst Mon-58, -60 and -62 are indicated with brown circles. AntACyV: ant associated cylcovirus; BatACyV: bat associated cyclovirus; BoACyV: bovine associated cyclovirus; ChickACyV: chicken associated cyclovirus; ChimpACyV: chimpanzee associated cyclovirus; CroACyV: cockroach associated cyclovirus; CyV: cyclovirus; DfACyV: dragonfly associated cycovirus; DuACyV: duck associated cyclovirus; FeACyV: feline associated cyclovirus; GoACyV: goat associated cyclovirus; HoACyV: horse associated cyclovirus; HuACyV: human associated cyclovirus; MoACyV: mouse associated cyclovirus; PffACyV: Pacific flying fox associated cyclovirus; RoACyV: rodent associated cyclovirus; SpACyV: spider associated cyclovirus; SqACyV: squirrel associated cyclovirus. 


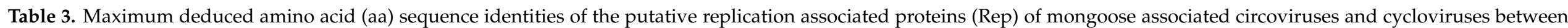
themselves and with those from other animal species.

\section{Maximum/Significant Pairwise Deduced aa Sequence (\%) Identities ${ }^{1}$}

\section{Mongoose associated circovirus}

Between mongoose
associated circoviruses

$99.70 \%$ with Mon-29
With circovirus/CRESS DNA Virus (Strain Name/Detected in Animal Species/Country/Year/GenBank Accession Number) from other animal species

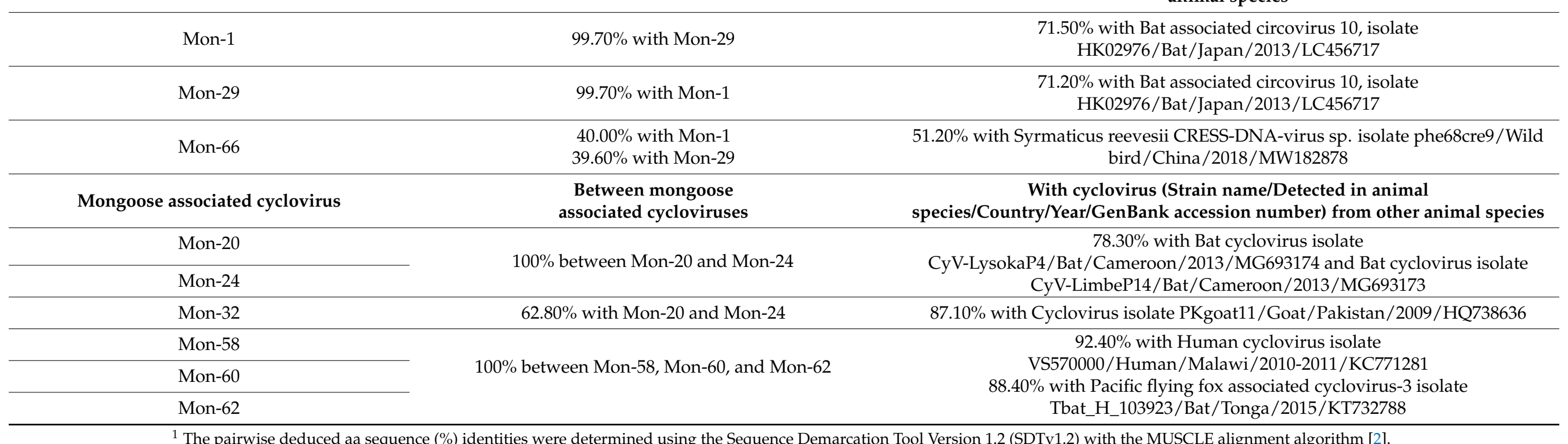

${ }^{1}$ The pairwise deduced aa sequence (\%) identities were determined using the Sequence Demarcation Tool Version 1.2 (SDTv1.2) with the MUSCLE alignment algorithm [2]. 


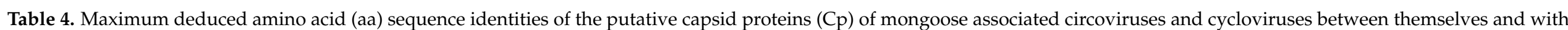
those from other animal species, or environmental samples.

\section{Maximum/Significant Pairwise Deduced aa Sequence (\%) Identities ${ }^{1}$}

\section{Mongoose associated circovirus}

\begin{tabular}{c}
\hline Mon-1 \\
\hline Mon-29 \\
\hline Mon-66
\end{tabular}

Mongoose associated cyclovirus

\begin{tabular}{cl}
\hline Mon-20 \\
\hline Mon-24 \\
\hline Mon-32 \\
\hline Mon-58
\end{tabular}

Mon-62
Mon-60

With circovirus/CRESS DNA Virus (Strain Name/Detected in Animal Species/Country/Year/GenBank Accession Number) from other animal species, or environmental samples

\section{Between mongoose associated circoviruses}

100\% between Mon-1 and Mon-29

24.40\% with Mon-1
and Mon-29

Between mongoose associated cycloviruses

100\% between Mon-20 and Mon-24

$35.90 \%$ with Mon-20 and Mon-24

$100 \%$ with Mon-62
$42.90 \%$ with Bat associated circovirus 10, isolate HK02976/Bat/Japan/2013/LC456717
${ }^{1}$ The pairwise deduced aa sequence (\%) identities were determined using the Sequence Demarcation Tool Version 1.2 (SDTv1.2) with the MUSCLE alignment algorithm [2].

With cyclovirus (Strain name/Detected in animal species/Country/Year/GenBank accession number) from other animal species $59.30 \%$ with Bat cyclovirus isolate

CyV-LysokaP4/Bat/Cameroon/2013/MG693174 and Bat cyclovirus isolate CyV-LimbeP14/Bat/Cameroon/2013/MG693173

$51.60 \%$ with Cyclovirus isolate PK5006/Human/Pakistan/2007/GQ404844 $56.10 \%$ with Pacific flying fox associated cyclovirus-3 isolate Tbat_H_103923/Bat/Tonga/2015/KT732788

$56.60 \%$ with Pacific flying fox associated cyclovirus-3 isolate Tbat_H_103923/Bat/Tonga/2015/KT732788

99.6\% with Mon-58 and Mon-62

$56.10 \%$ with Pacific flying fox associated cyclovirus-3 isolate 
The complete genome of Mon-66 was $2432 \mathrm{nt}$ long (Figure 2), which was larger than those of most circoviruses [1,2]. Even though the partial rep sequence of Mon-66 exhibited maximum homology with that of an unclassified CRESS DNA virus (Table 1), the complete genome of Mon-66 shared maximum pairwise identities of $60.70 \%$ with that of porcine circovirus 2 isolate MZ-5 (GenBank accession number LC004750) from India (Table 2). Since the genome-wide pairwise identity cut-off value for assigning a sequence to a genus within the family Circoviridae is 55\% [1,2], Mon-66 was classified as a circovirus. On the other hand, the Rep and Cp of Mon-66 shared maximum deduced aa identities of $51.20 \%$ and $44.40 \%$ with that of unclassified CRESS DNA viruses from a wild bird (MW182878) and a wastewater sample (KY487977), respectively (Tables 3 and 4). Phylogenetically, Mon-66 formed an isolated branch within the clade of circoviruses (Figure 5; Supplementary material S5).

The complete genomes of the mongoose associated cycloviruses were $1771 \mathrm{nt}, 1786 \mathrm{nt}$ or $1831 \mathrm{nt}$ long (Figure 2), which was within the size-range for cyclovirus genomes [1,2]. Mon-20 and -24 were fully identical in their complete genome sequences, and shared maximum homology (pairwise identities of $72.10 \%$ ) with that of bat cyclovirus isolate CyVLysokaP4 (GenBank accession number MG693174) from Cameroon (Table 2; Figure 6) [61]. Pairwise identities of the Rep and Cp, and phylogenetic analysis of Rep of Mon-20 and -24 also revealed similar findings (Tables 3 and 4; Supplementary material S5).

Mon-32 exhibited maximum pairwise identity of $77.30 \%$ with the complete genome of goat cyclovirus isolate PKgoat11, followed by $75.30 \%$ with that of human cyclovirus isolate PK5006 (GQ404844) (Table 2). Cyclovirus isolates PKgoat11 and PK5006 were detected in the same study from Pakistan [3]. The Rep and Cp of Mon-32 exhibited maximum pairwise deduced aa identity of $87.10 \%$ and $51.60 \%$ with that of isolates PKgoat 11 and PK5006, respectively (Tables 3 and 4). Phylogenetically, Mon-32 clustered with isolate PKgoat11 within a clade that also consisted of PK5006 (Figure 6; Supplementary material S5).

The Rep-encoding ORF of Mon-58, -60 and -62 was interrupted by a putative intron (nt 1610-nt 1511) with a canonical splice donor site (GT) and splice acceptor site (AG) (Supplementary material S7). The complete genomes of Mon-58, -60 and -62 shared 99.30-99.50\% pairwise identities between themselves, and maximum identities of 79.90$80.20 \%$ with those of human cyclovirus isolate VS570000 (GenBank accession number KC771281) from the CSF of a paraplegic patient in Malawi [36] and Pacific flying fox associated cyclovirus-3 isolate Tbat_H_103923 (KT732788) from the feces of a bat in Tonga (Table 2) [62]. Mon-58, -60 and -62 shared maximum pairwise identities of $92.40 \%$ with the Rep of isolate VS570000 (Table 3), and 56.10-56.60\% with the Cp of isolate Tbat_H_103923 (Table 4). By phylogenetic analysis, Mon-58, -60 and -62 clustered together near bat associated cycloviruses (including isolate Tbat_H_103923) [62] and the human cyclovirus isolate VS570000 (Figure 6; Supplementary material S5) [36].

The ICTV has recommended a species demarcation threshold of $80 \%$ genome-wide pairwise nt sequence identity for members of the family Circoviridae [1,2]. Based on the ICTV classification system, mongoose associated circoviruses Mon-1/Mon-29 and Mon-66 qualify as novel species within the genus Circovirus, whilst mongoose associated cycloviruses Mon-20/Mon-24 and Mon-32 represent new species in the genus Cyclovirus (Table 2; Supplementary Materials S3 and S4). On the other hand, the maximum pairwise identities (79.90-80.20\%) of mongoose associated cycloviruses Mon-58, -60 and -62 with cycloviruses from other animals/sources were borderline to the cut-off identity value for assigning novel cycloviral species (Table 2; Supplementary material S4).

\subsection{Conclusions}

Taken together, our findings suggest that CRESS DNA viruses are widely circulating in the small Indian mongoose population on the island of St. Kitts. However, in the absence of sampling from tissues, and considering that mongooses are polyphagous predators, we could not determine whether the circoviruses/cycloviruses in fecal samples of apparently healthy mongooses were of dietary origin, or actually infected the host. Based on the classification scheme proposed by the ICTV Circoviridae study group [1,2], we identified 
2 novel species in each of the genera Circovirus and Cyclovirus, further expanding the genetic diversity of these viruses. However, despite high genetic diversity, the mongoose associated circoviruses/cycloviruses retained the various features that are conserved among members of the family Circoviridae. Studies aimed at detection of viral DNA in tissues, screening for virus-specific antibodies, in-vitro replication of virus in mongoose cells and virus inoculation in gnotobiotic animals are required to gain a proper understanding of circovirus/cyclovirus infection in mongooses. To our knowledge, this is the first report on detection and complete genome analysis of circoviruses and cycloviruses in the small Indian mongoose, warranting further studies in other species of mongooses.

Supplementary Materials: The following are available online at https:/ / www.mdpi.com/article/10 .3390 /v13091700/s1, Supplementary material S1: Additional primers used in inverse nested PCRs to amplify the complete genomes of mongoose associated circoviruses and cycloviruses. Supplementary material S2: The presence of the arginine rich region in amino terminus of putative capsid proteins of mongoose associated circoviruses (Mon-1 and -29) and cycloviruses (Mon-20, -24, -32, $-58,-60$ and -62). Supplementary material S3: Two-dimensional graphical representation of pairwise nucleotide sequence (\%) identities between the complete genomes of circoviruses detected in various animal species. Supplementary material S4: Two-dimensional graphical representation of pairwise nucleotide sequence (\%) identities between the complete genomes of cycloviruses detected in various animal species. Supplementary material S5: Phylogenetic analysis of the putative replication-associated proteins (Rep) of mongoose associated circoviruses (A), and cycloviruses (B), Supplementary material S6: Identification of inter-species recombination event involving mongoose associated cyclovirus strain Mon-32, as determined by the Recombination Detection Program (RDP v.4.101). Supplementary material S7: BLASTN (with coding sequence (CDS) feature) analysis showing the alignment of the putative replication associated protein (Rep) CDS (shown with brown line) of mongoose associated cyclovirus Mon-58 (Query sequence, Rep CDS: join nt 1771-nt 1611, nt 1512-nt 840) with that of Pacific flying fox associated cyclovirus-3 isolate Tbat_H_103923 (GenBank accession number KT732788) (Subject (Sbjct) sequence, Rep CDS: join nt 1788-nt 1628, nt 1515-nt 843).

Author Contributions: Conceptualization, K.G. and S.G.; collected samples, A.A.M.J.B.; secured funding, S.G.; contributed reagents, S.G.; screened samples, K.G. and S.G.; performed laboratory work, K.G. and S.G.; performed data analysis, K.G. and S.G.; wrote the manuscript, K.G. and S.G.; edited and finalized the manuscript, A.A.M.J.B., K.G., S.G. and Y.S.M. All authors have read and agreed to the published version of the manuscript.

Funding: The present study was funded by intramural grant \# Viruses 41001-21 entitled 'Detection and molecular characterization of viruses in pigs and wildlife in the Caribbean and Central America from the One Health Center for Zoonoses and Tropical Veterinary Medicine, Ross University School of Veterinary Medicine, St. Kitts and Nevis.

Institutional Review Board Statement: This study was approved by the Institutional Animal Care and Use Committee (IACUC) of the Ross University School of Veterinary Medicine, St. Kitts and Nevis (IACUC protocol title: trapping and necropsy for mongoose microbial ecology study. Approved IACUC protocol number: 17.04.13, dated 13 April 2017).

Informed Consent Statement: Not applicable.

Acknowledgments: We would like to thank DVM research assistant/volunteers KC Hill, Vania Monsul and Elizabeth Coloian from the Ross University School of Veterinary Medicine (RUSVM), St. Kitts and Nevis, for assisting with sampling/laboratory work.

Conflicts of Interest: The authors declare no conflict of interest.

\section{References}

1. Breitbart, M.; Delwart, E.; Rosario, K.; Segalés, J.; Varsani, A. ICTV virus taxonomy profile: Circoviridae. J. Gen. Virol. 2017, 98, 1997-1998. [CrossRef]

2. Rosario, K.; Breitbart, M.; Harrach, B.; Segalés, J.; Delwart, E.; Biagini, P.; Varsani, A. Revisiting the taxonomy of the family Circoviridae: Establishment of the genus Cyclovirus and removal of the genus Gyrovirus. Arch. Virol. 2017, 162, 1447-1463. [CrossRef] 
3. Li, L.; Kapoor, A.; Slikas, B.; Bamidele, O.S.; Wang, C.; Shaukat, S.; Masroor, M.A.; Wilson, M.L.; Ndjango, J.-B.N.; Peeters, M.; et al. Multiple Diverse Circoviruses Infect Farm Animals and Are Commonly Found in Human and Chimpanzee Feces. J. Virol. 2010, 84, 1674-1682. [CrossRef]

4. Zhao, L.; Rosario, K.; Breitbart, M.; Duffy, S. Eukaryotic Circular Rep-Encoding Single-Stranded DNA (CRESS DNA) Viruses: Ubiquitous Viruses with Small Genomes and a Diverse Host Range. Adv. Virus Res. 2019, 103, 71-133. [CrossRef]

5. Delwart, E.; Li, L. Rapidly expanding genetic diversity and host range of the Circoviridae viral family and other Rep encoding small circular ssDNA genomes. Virus Res. 2012, 164, 114-121. [CrossRef] [PubMed]

6. Steinfeldt, T.; Finsterbusch, T.; Mankertz, A. Demonstration of Nicking/Joining Activity at the Origin of DNA Replication Associated with the Rep and Rep' Proteins of Porcine Circovirus Type 1. J. Virol. 2006, 80, 6225-6234. [CrossRef] [PubMed]

7. Cheung, A.K. Identification of an octanucleotide motif sequence essential for viral protein, DNA, and progeny virus biosynthesis at the origin of DNA replication of porcine circovirus type 2. Virology 2004, 324, 28-36. [CrossRef] [PubMed]

8. Alex, C.E.; Fahsbender, E.; Altan, E.; Bildfell, R.; Wolff, P.; Jin, L.; Black, W.; Jackson, K.; Woods, L.; Munk, B.; et al. Viruses in unexplained encephalitis cases in american black bears (ursus americanus). PLoS ONE 2020, 15, e0244056. [CrossRef] [PubMed]

9. Fisher, M.; Harrison, T.M.R.; Nebroski, M.; Kruczkiewicz, P.; Rothenburger, J.L.; Ambagala, A.; Macbeth, B.; Lung, O. Discovery and comparative genomic analysis of elk circovirus (elkcv), a novel circovirus species and the first reported from a cervid host. Sci. Rep. 2020, 10, 19548. [CrossRef]

10. Payne, N.; Kraberger, S.; Fontenele, R.S.; Schmidlin, K.; Bergeman, M.H.; Cassaigne, I.; Culver, M.; Varsani, A.; Van Doorslaer, K. Novel circoviruses detected in feces of sonoran felids. Viruses 2020, 12, 1027. [CrossRef] [PubMed]

11. Tisza, M.J.; Pastrana, D.V.; Welch, N.L.; Stewart, B.; Peretti, A.; Starrett, G.J.; Pang, Y.S.; Krishnamurthy, S.R.; Pesavento, P.A.; McDermott, D.H.; et al. Discovery of several thousand highly diverse circular DNA viruses. Elife 2020, 9, e51971. [CrossRef] [PubMed]

12. Nishizawa, T.; Sugimoto, Y.; Takeda, T.; Kodera, Y.; Hatano, Y.; Takahashi, M.; Okamoto, H. Identification and full-genome characterization of novel circoviruses in masked palm civets (Paguma larvata). Virus Res. 2018, 258, 50-54. [CrossRef] [PubMed]

13. Nebbak, A.; Monteil-Bouchard, S.; Berenger, J.M.; Almeras, L.; Parola, P.; Desnues, C. Virome diversity among mosquito populations in a sub-urban region of Marseille, France. Viruses 2021, 13, 768. [CrossRef]

14. Wu, Z.; Lu, L.; Du, J.; Yang, L.; Ren, X.; Liu, B.; Jiang, J.; Yang, J.; Dong, J.; Sun, L.; et al. Comparative analysis of rodent and small mammal viromes to better understand the wildlife origin of emerging infectious diseases. Microbiome 2018, 6, 178. [CrossRef]

15. Hui, A.; Altan, E.; Slovis, N.; Fletcher, C.; Deng, X.; Delwart, E. Circovirus in blood of a febrile horse with hepatitis. Viruses 2021, 13, 944. [CrossRef]

16. Zhang, H.H.; Hu, W.Q.; Li, J.Y.; Liu, T.N.; Zhou, J.Y.; Opriessnig, T.; Xiao, C.T. Novel circovirus species identified in farmed pigs designated as porcine circovirus 4, hunan province, china. Transbound. Emerg. Dis. 2020, 67, 1057-1061. [CrossRef] [PubMed]

17. Kleymann, A.; Soto, E.; Illanes, O.; Malik, Y.S.; Fuentealba, C.; Ghosh, S. High rates of detection and complete genomic analysis of porcine circovirus 2 (PCV2) in the Lesser Antilles island of St. Kitts: Identification of PCV2b-PCV2d recombinants. Transbound. Emerg. Dis. 2020, 67, 2282-2289. [CrossRef]

18. Bandoo, R.A.; Bautista, J.; Lund, M.; Newkirk, E.; Squires, J.; Varsani, A.; Kraberger, S. Identification of novel circovirus and anelloviruses from wolverines using a non-invasive faecal sampling approach. Infect. Genet. Evol. 2021, 93, 104914. [CrossRef]

19. Prades, Y.; Pizarro, R.; Ruiz, M.; Moreno, C.; Avendaño, L.F.; Luchsinger, V. Cyclovirus detection in Chilean adults with and without community-acquired pneumonia. J. Med. Virol. 2021, 93, 4786-4793. [CrossRef]

20. Sasaki, M.; Orba, Y.; Ueno, K.; Ishii, A.; Moonga, L.; Hangombe, B.M.; Mweene, A.S.; Ito, K.; Sawa, H. Metagenomic analysis of the shrew enteric virome reveals novel viruses related to human stool-associated viruses. J. Gen. Virol. 2015, 96, 440-452. [CrossRef]

21. Rosario, K.; Mettel, K.A.; Benner, B.E.; Johnson, R.; Scott, C.; Yusseff-Vanegas, S.Z.; Baker, C.C.M.; Cassill, D.L.; Storer, C.; Varsani, A.; et al. Virus discovery in all three major lineages of terrestrial arthropods highlights the diversity of single-stranded DNA viruses associated with invertebrates. Peer] 2018, 6, e5761. [CrossRef] [PubMed]

22. Liu, Q.; Wang, H.; Ling, Y.; Yang, S.X.; Wang, X.C.; Zhou, R.; Xiao, Y.Q.; Chen, X.; Yang, J.; Fu, W.G.; et al. Viral metagenomics revealed diverse CRESS-DNA virus genomes in faeces of forest musk deer. Virol. J. 2020, 17, 61. [CrossRef]

23. Dennis, T.P.W.; Flynn, P.J.; de Souza, W.M.; Singer, J.B.; Moreau, C.S.; Wilson, S.J.; Gifford, R.J. Insights into Circovirus Host Range from the Genomic Fossil Record. J. Virol. 2018, 92, e00145-18. [CrossRef] [PubMed]

24. Altan, E.; Kubiski, S.V.; Burchell, J.; Bicknese, E.; Deng, X.; Delwart, E. The first reptilian circovirus identified infects gut and liver tissues of black-headed pythons. Vet. Res. 2019, 50, 35. [CrossRef] [PubMed]

25. Chang, W.S.; Li, C.X.; Hall, J.; Eden, J.S.; Hyndman, T.H.; Holmes, E.C.; Rose, K. Meta-transcriptomic discovery of a divergent circovirus and a chaphamaparvovirus in captive reptiles with proliferative respiratory syndrome. Viruses 2020, $12,1073$. [CrossRef] [PubMed]

26. Lorincz, M.; Cságola, A.; Farkas, S.L.; Székely, C.; Tuboly, T. First detection and analysis of a fish circovirus. J. Gen. Virol. 2011, 92, 1817-1821. [CrossRef] [PubMed]

27. Lorincz, M.; Dan, A.; Lang, M.; Csaba, G.; Toth, A.G.; Szekely, C.; Csagola, A.; Tuboly, T. Novel circovirus in european catfish (Silurus glanis). Arch. Virol. 2012, 157, 1173-1176. [CrossRef]

28. Doszpoly, A.; Tarján, Z.L.; Glávits, R.; Müller, T.; Benko, M. Full genome sequence of a novel circo-like virus detected in an adult European eel Anguilla anguilla showing signs of cauliflower disease. Dis. Aquat. Organ. 2014, 109, 107-115. [CrossRef] 
29. Opriessnig, T.; Karuppannan, A.K.; Castro, A.M.M.G.; Xiao, C.T. Porcine circoviruses: Current status, knowledge gaps and challenges. Virus Res. 2020, 286, 198044. [CrossRef]

30. Fogell, D.J.; Martin, R.O.; Groombridge, J.J. Beak and feather disease virus in wild and captive parrots: An analysis of geographic and taxonomic distribution and methodological trends. Arch. Virol. 2016, 161, 2059-2074. [CrossRef]

31. Soike, D.; Köhler, B.; Albrecht, K. A circovirus-like infection in geese related to a runting syndrome. Avian Pathol. 1999, 28, 199-202. [CrossRef]

32. Stenzel, T.; Koncicki, A. The epidemiology, molecular characterization and clinical pathology of circovirus infections in pigeonsCurrent knowledge. Vet. Q. 2017, 37, 166-174. [CrossRef]

33. Li, L.; McGraw, S.; Zhu, K.; Leutenegger, C.M.; Marks, S.L.; Kubiski, S.; Gaffney, P.; Cruz, F.N.D.; Wang, C.; Delwart, E.; et al. Circovirus in tissues of dogs with vasculitis and hemorrhage. Emerg. Infect. Dis. 2013, 19, 534-541. [CrossRef] [PubMed]

34. Van Kruiningen, H.J.; Heishima, M.; Kerr, K.M.; Garmendia, A.E.; Helal, Z.; Smyth, J.A. Canine circoviral hemorrhagic enteritis in a dog in Connecticut. J. Vet. Diagn. Investig. 2019, 31, 732-736. [CrossRef] [PubMed]

35. Lian, H.; Liu, Y.; Li, N.; Wang, Y.; Zhang, S.; Hu, R. Novel circovirus from mink, China. Emerg. Infect. Dis. 2014, 20, 1548-1550. [CrossRef]

36. Smits, S.L.; Zijlstra, E.E.; van Hellemond, J.J.; Schapendonk, C.M.E.; Bodewes, R.; Schürch, A.C.; Haagmans, B.L.; Osterhaus, A.D.M.E. Novel cyclovirus in human cerebrospinal fluid, Malawi, 2010-2011. Emerg. Infect. Dis. 2013, 19, 1511-1513. [CrossRef] [PubMed]

37. Barun, A.; Hanson, C.C.; Campell, K.J.; Simberlo, D. A review of small Indian mongoose management and eradications on islands. In Island Invasives: Eradication and Management; Veitch, C.R., Clout, M.N., Towns, D.R., Eds.; IUCN: Gland, Switzerland, 2011; pp. $17-25$.

38. Veron, G.; Jennings, A.P. Javan mongoose or small Indian mongoose-Who is where? Mamm. Biol. 2017, 87, 62-70. [CrossRef]

39. Sauvé, C.C.; Rees, E.E.; Gilbert, A.T.; Berentsen, A.R.; Allibert, A.; Leighton, P.A. Modeling mongoose rabies in the caribbean: A model-Guided fieldwork approach to identify research priorities. Viruses 2021, 13, 323. [CrossRef]

40. Nidaira, M.; Takahashi, K.; Ogura, G.; Taira, K.; Okano, S.; Kudaka, J.; Itokazu, K.; Mishiro, S.; Nakamura, M. Detection and phylogenetic analysis of Hepatitis E Viruses from mongooses in Okinawa, Japan. J. Vet. Med. Sci. 2012, 74, 1665-1668. [CrossRef]

41. Chang, A.M.; Chen, C.C. Molecular characteristics of Carnivore protoparvovirus 1 with high sequence similarity between wild and domestic carnivores in Taiwan. Pathogens 2021, 10, 671. [CrossRef]

42. Schmiedeknecht, G.; Eickmann, M.; Köhler, K.; Herden, C.E.; Kolesnikova, L.; Förster, C.; Burkhardt, E.H.; König, M.; Thiel, M.; Reinacher, M. Fatal cowpox virus infection in captive Banded mongooses (Mungos mungo). Vet. Pathol. 2010, 47, 547-552. [CrossRef]

43. Duarte, M.D.; Henriques, A.M.; Barros, S.C.; Fagulha, T.; Mendonça, P.; Carvalho, P.; Monteiro, M.; Fevereiro, M.; Basto, M.P.; Rosalino, L.M.; et al. Snapshot of Viral Infections in Wild Carnivores Reveals Ubiquity of Parvovirus and Susceptibility of Egyptian Mongoose to Feline Panleukopenia Virus. PLoS ONE 2013, 8, e59399. [CrossRef]

44. Kleymann, A.; Becker, A.A.M.J.; Malik, Y.S.; Kobayashi, N.; Ghosh, S. Detection and molecular characterization of picobirnaviruses (PBVs) in the mongoose: Identification of a novel PBV using an alternative genetic code. Viruses 2020, 12, 99. [CrossRef]

45. Ogen-Odoi, A.; Miller, B.R.; Happ, C.M.; Maupin, G.O.; Burkot, T.R. Isolation of thogoto virus (Orthomyxoviridae) from the banded mongoose, Mongos mungo (herpestidae), in Uganda. Am. J. Trop. Med. Hyg. 1999, 60, 439-440. [CrossRef]

46. Conceição-Neto, N.; Zeller, M.; Heylen, E.; Lefrère, H.; Mesquita, J.R.; Matthijnssens, J. Fecal virome analysis of three carnivores reveals a novel nodavirus and multiple gemycircularviruses. Virol. J. 2015, 12, 79. [CrossRef] [PubMed]

47. Becker, A.A.M.J.; Hill, K.C.; Butaye, P. Unraveling the gut microbiome of the invasive small Indian mongoose (Urva auropunctata) in the Caribbean. Microorganisms 2021, 9, 465. [CrossRef] [PubMed]

48. Muhire, B.M.; Varsani, A.; Martin, D.P. SDT: A virus classification tool based on pairwise sequence alignment and identity calculation. PLoS ONE 2014, 9, e108277. [CrossRef]

49. Zuker, M. Mfold web server for nucleic acid folding and hybridization prediction. Nucleic Acids Res. 2003, 31, 3406-3415. [CrossRef] [PubMed]

50. Kumar, S.; Stecher, G.; Tamura, K. MEGA7: Molecular Evolutionary Genetics Analysis Version 7.0 for Bigger Datasets. Mol. Biol. Evol. 2016, 33, 1870-1874. [CrossRef] [PubMed]

51. Martin, D.P.; Murrell, B.; Golden, M.; Khoosal, A.; Muhire, B. RDP4: Detection and analysis of recombination patterns in virus genomes. Virus Evol. 2015, 1, vev003. [CrossRef]

52. Cheng, T.; Halper, B.; Siebert, J.; Cruz-Martinez, L.; Chapwanya, A.; Kelly, P.; Ketzis, J.K.; Vessell, J.; Köster, L.; Yao, C. Parasites of small Indian mongoose, Herpestes auropunctatus, on St. Kitts, West Indies. Parasitol. Res. 2018, 117, 989-994. [CrossRef]

53. Louppe, V.; Leroy, B.; Herrel, A.; Veron, G. The globally invasive small Indian mongoose Urva auropunctata is likely to spread with climate change. Sci. Rep. 2020, 10, 7461. [CrossRef] [PubMed]

54. Li, L.; Shan, T.; Soji, O.B.; Alam, M.M.; Kunz, T.H.; Zaidi, S.Z.; Delwart, E. Possible cross-species transmission of circoviruses and cycloviruses among farm animals. J. Gen. Virol. 2011, 92, 768-772. [CrossRef]

55. Reeves, W.K.; Beck, J.; Orlova, M.V.; Daly, J.L.; Pippin, K.; Revan, F.; Loftis, A.D. Ecology of Bats, Their Ectoparasites, and Associated Pathogens on Saint Kitts Island. J. Med. Entomol. 2016, 53, 1218-1225. [CrossRef]

56. Dayaram, A.; Potter, K.A.; Moline, A.B.; Rosenstein, D.D.; Marinov, M.; Thomas, J.E.; Breitbart, M.; Rosario, K.; Argüello-Astorga, G.R.; Varsani, A. High global diversity of cycloviruses amongst dragonflies. J. Gen. Virol. 2013, 94, 1827-1840. [CrossRef] 
57. Heath, L.; Martin, D.P.; Warburton, L.; Perrin, M.; Horsfield, W.; Kingsley, C.; Rybicki, E.P.; Williamson, A.-L. Evidence of Unique Genotypes of Beak and Feather Disease Virus in Southern Africa. J. Virol. 2004, 78, 9277-9284. [CrossRef] [PubMed]

58. Kaszab, E.; Lengyel, G.; Marton, S.; Dán, Á.; Bányai, K.; Fehér, E. Occurrence and genetic diversity of CRESS DNA viruses in wild birds: A Hungarian study. Sci. Rep. 2020, 10, 7036. [CrossRef] [PubMed]

59. Wu, Z.; Yang, L.; Ren, X.; He, G.; Zhang, J.; Yang, J.; Qian, Z.; Dong, J.; Sun, L.; Zhu, Y.; et al. Deciphering the bat virome catalog to better understand the ecological diversity of bat viruses and the bat origin of emerging infectious diseases. ISME J. 2016, 10, 609-620. [CrossRef]

60. Matsumoto, T.; Sato, M.; Nishizono, A.; Ahmed, K. A novel bat-associated circovirus identified in northern Hokkaido, Japan. Arch. Virol. 2019, 164, 2179-2182. [CrossRef]

61. Yinda, C.K.; Ghogomu, S.M.; Conceição-Neto, N.; Beller, L.; Deboutte, W.; Vanhulle, E.; Maes, P.; Van Ranst, M.; Matthijnssens, J. Cameroonian fruit bats harbor divergent viruses, including rotavirus $\mathrm{H}$, bastroviruses, and picobirnaviruses using an alternative genetic code. Virus Evol. 2018, 4, vey008. [CrossRef]

62. Male, M.F.; Kraberger, S.; Stainton, D.; Kami, V.; Varsani, A. Cycloviruses, gemycircularviruses and other novel replicationassociated protein encoding circular viruses in Pacific flying fox (Pteropus tonganus) faeces. Infect. Genet. Evol. 2016, 39, 279-292. [CrossRef] [PubMed] 